\title{
ІНФОРМАЦІЙНІ ТЕХНОЛОГІЇ В НАВЧАННІ СТУДЕНТІВ НА КАФЕДРІ АНАТОМІї ЛЮДИНИ ІМ. М. Г. ТУРКЕВИЧА
}

\author{
В. В. Кривецький, Б. Г. Макар, Ф. Д. Марчук \\ Буковинський державний медичний університет
}

\section{INFORMATION TECHNOLOGIES IN TEACHING OF STUDENTS AT THE ANATOMY DEPARTMENT BY M. H. TURKEVYCH}

\author{
V. V. Kryvetskyi, B. H. Makar, F. D. Marchuk \\ Bukovynian State Medical University
}

\begin{abstract}
У статті висвітлено перспективи використання інноваційних технологій у новій освітній моделі та власний досвід організації викладання нормальної анатомії людини студентам медичних факультетів.
\end{abstract}

The article adduces the prospects of using of innovative technologies in the new educational model and own experience of teaching organization of the Normal Human Anatomy for students of medical faculties.

Вступ. Основні переваги сучасних інформаційних технологій (наочність, можливість використання комбінованих форм представлення інформації-дані, стереозвучання, графічне зображення, анімація, обробка та зберігання великих обсягів інформації, доступ до світових інформаційних ресурсів) повинні стати основою підтримки процесу освіти [1-3].

Посилення ролі самостійної роботи студента дозволяє внести істотні зміни в структуру та організацію навчального процесу, підвищити ефективність $і$ якість навчання, активізувати мотивацію пізнавальної діяльності в процесі навчання [4].

Основна частина. Основні фактори, що впливають на ефективність використання інформаційних ресурсів в освітньому процесі:

1. Інформаційне перевантаження студентів - це реальність. Надлишок даних служить причиною зниження якості мислення передусім серед освічених членів сучасного суспільства.

2. Впровадження сучасних інформаційних технологій доцільно в тому випадку, якщо це дозволяє створити додаткові можливості в таких напрямках:

- доступ до великого обсягу навчальної інформації;

- образна наочна форма представлення досліджуваного матеріалу;

- підтримка активних методів навчання;

- можливість вкладеного модульного представлення інформації.

3. Виконання таких дидактичних вимог, як:

- доцільність подання навчального матеріалу;
- достатність, наочність, повнота, сучасність та структурованість навчального матеріалу;

- багатошаровість представлення навчального матеріалу за рівнем складності;

- своєчасність і повнота контрольних питань і тестів;

- протоколювання дій під час роботи;

- інтерактивність, можливість вибору режиму роботи 3 навчальним матеріалом;

- наявність у кожному предметі основної, інваріантної та варіативної частин, які можуть коригуватися.

4. Комп'ютерна підтримка кожного досліджуваного предмета, і цей процес не можна підмінити вивченням єдиного курсу інформатики.

Позитивним при використанні інформаційних технологій в освітіє підвищення якості навчання за рахунок:

- більшої адаптації студента до навчального матеріалу з урахуванням власних можливостей і здібностей;

- можливості вибору більш відповідного для студента методу засвоєння предмета;

- регулювання інтенсивності навчання на різних етапах навчального процесу;

- самоконтролю;

- доступу до раніше недосяжних освітніх ресурсів українського і світового рівнів;

- підтримки активних методів навчання;

- образної наочної форми подання матеріалу, що вивчається;

- модульного принципу побудови, що дозволяє тиражувати окремі складові частини інформаційної технологіi;

(ㄱ В. В. Кривецький, Б. Г. Макар, Ф. Д. Марчук 
- розвитку самостійного навчання.

У даний час отримали широке застосування такі напрямки використання інформаційних технологій:

1. Комп'ютерні програми і навчальні системи, що являють собою:

- комп'ютерні підручники, призначені для формування нових знань і навичок;

- діагностичні або тестові системи, призначені для діагностування, оцінювання і перевірки знань, здібностей і вмінь;

- тренажери й імітаційні програми, що представляють той чи інший аспект реальності, що відображають його основні структурні та функціональні характеристики і призначені для формування практичних навичок;

- лабораторні комплекси, в основі яких лежать моделюючі програми, які надають можливості використання математичної моделі для дослідження певної реальності;

- експертні системи, призначені для навчання навичкам прийняття рішень на основі накопиченого досвіду і знань;

- бази даних і бази знань з різноманітних галузей, що забезпечують доступ до накопичених знань;

- прикладні та інструментальні програмні засоби, що забезпечують виконання конкретних навчальних операцій (опрацювання текстів, складання таблиць, редагування графічної інформації та ін.).

2. Системи на базі мультимедіа-технології, побудовані із застосуванням відеотехніки, накопичувачів на DVD-ROM.

3. Інтелектуальні навчальні експертні системи, які спеціалізуються 3 конкретних сфер застосування і мають практичне значення як у процесі навчання, так і в навчальних дослідженнях.

4. Інформаційні середовища на основі баз даних i баз знань, що дозволяють здійснити як прямий, так i віддалений доступ до інформаційних ресурсів.

5. Телекомунікаційні системи, що реалізують електронну пошту, телеконференції і т. д. і дозволяють здійснити вихід у світові комунікаційні мережі.

6. Електронні настільні друкарні, що дозволяють в індивідуальному режимі 3 високою швидкістю здійснити випуск навчальних посібників і документів на різних носіях.

7. Електронні бібліотеки як розподіленого, так і централізованого характеру, що дозволяють по-новому реалізувати доступ студентів до світових інформаційних ресурсів.

8. Системи захисту інформації різної орієнтації (від несанкціонованого доступу при зберіганні, від спотворень при передачі і т. д.).
При створенні комп'ютерних навчальних засобів можуть бути використані різні базові інформаційні технології. Нові можливості, що відкриваються при впровадженні сучасних інформаційних технологій в освіті, можна проілюструвати на прикладі мультимедіа-технологій. 3'явилася можливість створювати підручники, навчальні посібники та інші методичні матеріали на машинному носії. Вони можуть бути розділені на такі групи:

1. Підручники, що являють собою текстовий виклад матеріалу з великим числом ілюстрацій, які можуть бути встановлені на сервері і передані через мережу на домашній комп'ютер. При обмеженій кількості матеріалу такий підручник може бути реалізований в прямому доступі користувача до сервера.

2. Підручники з високою динамікою ілюстративного матеріалу, виконані на DVD-ROM. Поряд з основним матеріалом вони містять засоби інтерактивного доступу, анімації та мультиплікації, а також відеозображення, в динаміці демонструють принципи i способи реалізації окремих процесів і явищ. Такі підручники можуть мати не тільки освітнє, а й художнє призначення. Величезний обсяг пам'яті носія інформації дозволяє реалізовувати на одному оптичному диску енциклопедію, довідник, путівник і т. д.

3. Сучасні комп'ютерні навчальні системи для проведення навчально-дослідних робіт. Вони реалізують моделювання як процесів, так і явищ, тобто створюють нове навчальне комп'ютерне середовище, в якому студент $є$ активним учасником і може сам вести навчальний процес.

4. Системи віртуальної реальності, в яких студент стає учасником комп'ютерної моделі, що відображає навколишній світ. Для грамотного використання мультимедіа-продуктів цього типу вкрай важливо вивчення їх психологічних особливостей та негативних впливів на студента.

5. Системи дистанційного навчання. У складних соціально-економічних умовах дистанційна освіта стає особливо актуальною для віддалених регіонів, для людей $з$ малою рухливістю, а також при самоосвіті та самостійній роботі студентів. Ефективна реалізація дистанційного навчання можлива лише за цілеспрямованої програми створення високоякісних мультимедіа-продуктів навчального призначення 3 морфологічних дисциплін. Реалізація такої програми дозволить по-новому організувати навчальний процес, збільшивши навантаження на самостійну роботу студента.

У процесі інформатизації освіти необхідно мати на увазі, що головний принцип використання комп’юте- 
ра-це орієнтація на ті випадки, коли людина не може виконати поставлене педагогічне завдання. Наприклад, викладач не може наочно продемонструвати більшість фізичних процесів без комп'ютерного моделювання. 3 іншого боку, комп'ютер повинен допомагати розвитку творчих здібностей студента, сприяти навчанню нових професійних навичок і вмінь, розвитку логічного мислення. Процес навчання повинен бути спрямований не на вміння працювати 3 певними програмними засобами, а на технології роботи з різною інформацією: аудіо- та відео-, графічною, текстовою, табличною.

Сучасні інструментальні засоби дозволяють реалізувати всю гаму комп'ютерних навчальних засобів. Проте їх використання вимагає досить високої кваліфікації користувача. Більша частина навчальних програмних продуктів являє собою аналоги існуючих

\section{Література}

1. Волосовець О. П. Питання якості освіти у контексті впровадження засад Болонської декларації у вищій медичній школі / О. П. Волосовець // Медична освіта. - 2005.-№ 2. C. $12-16$.

2. Дистанційні технології навчання як одна з інноваційних технологій у навчальному процесі / I. В. Геруш, В. А. Гайдуков, Ю. С. Букатару, І. М. Маринчин // Медична підручників. Більш правильним $€$ використання інформаційних технологій для вивчення процесів і явищ, які не піддаються візуальному дослідженню та вивченню на основі існуючих освітніх технологій. Іншою сферою застосування інформаційних технологій $\epsilon$ домашня освіта.

Висновок. Одним з напрямків інформатизації сфери освіти, пропонованих кафедрою, $є$ розробка і поставка комплексних рішень, що включають апаратне і програмне забезпечення, а також методичний супровід. Використання комп'ютерів Macintosh пов'язано з тим, що фірма Apple одна з небагатьох орієнтувала свою діяльність спеціально на освіту.

Перехід від консервативної освітньої системи до випереджаючої повинен базуватися на випереджаючому формуванні інформаційного простору української освіти іширокому використанні інформаційних технологій.

освіта. -2012.- №3.- - С. 35-37.

3. Роль сучасних технологій у становленні майбутніх лікарів / В. М. Ждан, В. М. Бобирьов, О. В. Шешукова [та ін.] // Медична освіта. -2012. - № 3. - С. 35-37.

4. Основні засади розвитку вищої освіти України / за редакцією І. О. Вакарчука. Частина 4. - К. : Вид-во НПУ ім. М. П. Драгоманова, 2008. - 173 с. 